\title{
Characterization and nutritional values of four tomato varieties in climatic conditions of District Layyah, Pakistan
}

\author{
Sumaira Thind ${ }^{1}$, Tanveer Hussain ${ }^{2 *}$ and Iqbal Hussain ${ }^{1}$ \\ 1. Department of Botany, Government College University Faisalabad-38000-Pakistan \\ 2. Department of Botany, Mirpur University of Science and Technology (MUST), Mirpur Azad Kashmir-Pakistan \\ *Corresponding author's email: tanveerajk@gmail.com \\ Citation \\ Sumaira Thind, Tanveer Hussain and Iqbal Hussain. Characterization and nutritional values of four tomato varieties \\ in climatic conditions of district Layyah, Pakistan. Pure and Applied Biology. Vol. 7, Issue 2, pp810-818. \\ http://dx.doi.org/10.19045/bspab.2018.700100
}

\begin{tabular}{llll}
\hline \hline Received: 04/03/2018 & Revised: 13/06/2018 & Accepted: 22/06/2018 & Online First: 29/06/2018 \\
\hline \hline
\end{tabular}

\section{Abstract}

This research work was conducted at District Layyah to evaluate the impact of ecoclimatic conditions, soils texture on growth parameters and nutritional values of three tomato varieties. The tested varieties were DT97/162A(R), DT97/215.A, local $\mathrm{V}_{1}$ and local $\mathrm{V}_{2}$. They were assigned randomly into different blocks in the fields as completely randomized block design (RBCD). In present results, physio-chemical properties of soil, nutritional values and morphometric characteristics of three tomato varieties were analyzed and documented. The $\mathrm{pH} 7.6$ was measured. Available Phosphorus was calculated as $7.8 \mathrm{mg} / \mathrm{kg}$. Total Nitrogen appeared in collected samples was $0.6 \%$. $\mathrm{Ca}^{2+}$ indicated maximum exchangeable cation $(2.9 \mathrm{mg} / \mathrm{g})$ as comparison to other cations. In exchangeable acidity, Fe (ppm) indicated highest value (19.4 meg/100g). Maximum $(42.55 \%)$ protein percentage produced by local variety $\mathrm{V}_{2}$ while highest $(41.50 \%)$ fat shown by variety DT97/162A(R). Fiber percentage appeared almost similar in all analyzed varieties. Vitamin $\mathrm{C}(0.37 \mathrm{mg} / 100 \mathrm{~g})$ was measured highest in local variety $\mathrm{V}_{2}$. The highest values of $\mathrm{Ca}(0.395 \%)$, $\mathrm{Mg}(0.215 \%), \mathrm{K}(0.182 \%)$ and $\mathrm{P}(0.572 \%)$ were also observed in tomato local variety $\mathrm{V}_{2}$. However, tomato variety local $\mathrm{V}_{2}$ showed higher plant height. Tomato variety DT97/162A(R) showed highest number of leaves while DT97/215A indicated minimum values. Number of flowers and number of fruits were produced almost similar in all varieties. Hence, local variety $V_{2}$ showed highest growth, better yield performance and high nutritional values. Therefore, it is concluded that a local variety $\left(\mathrm{V}_{2}\right)$ suggested as the suitable tomato variety for the environmental conditions of District Layyah, Pakistan.

Keywords: Climatic conditions; Growth parameters; Nutritional values; Tomato varieties

\section{Introduction}

Now a day, demand of food production is a main thread to achieve the requirements of increasing populations in sector of agriculture. It will be spreading day by day and continually explore in future due to overpopulation. Crop quality depends on many factors for better food production and one of the main key factor is their system of fertilization. The growth and production of different vegetable crops are mainly depends on the quantity and quality of fertilizers [1]. So, different chemical fertilizers are often used to increase yield of crop as well as 
increase soil fertility. Frequent use of these fertilizers correlates with ecoclimatic conditions and high rates of inorganic fertilizer have been influenced on some environmental pollution, modify soil textures and physical property of fertile soil. Moreover, the nutritional values of crops are also affected by continuous use of various synthetic fertilizers. Therefore, these fertilizers have both good and bad impacts on varieties of tomato. Farmers should try to improve tomato yield by alternate way of fertility in soil instead of adequate use of fertilizers [2].

Lycopersicum esculentum Mill. (Tomato) is the most important vegetable commonly used in different parts of the world. It is estimated that tomato crop is relatively very short duration crop as comparison to other crops. It produces good yield in a short duration. It is economically most attractive vegetable and the area under cultivation of the crop is increasing day by day [3]. Moreover, tomatoes contain a healthy, well balanced diet and rich in essential amino acids, minerals, vitamin $\mathrm{B}, \mathrm{C}$ and $\mathrm{E}$, iron and phosphorus, sugars and dietary fibers. Fresh tomatoes are used in making salads and good for soup. This vegetable is also used in cooking of meat and fish dishes. Tomato juices, pickled, ketchup and other forms of tomato are very common in food industry. Dried tomatoes and canned products of tomatoes are economically important everywhere in the world.

According to a rough estimation, every year 20 million metric tons (MMT) tomatoes were produced in the world. The United States, Spain, UAR and Italy are the leading producers of tomato crop. Among vegetable crops in the USA alone ranked on $2^{\text {nd }}$ number in production of potatoes and contributes much more in his economy. It was estimated approximately 400 million dollars contributed in economy during each year [4]. In year 2010, global production of fresh fruit was approximately 145.6 million tons with $2.7 \%$ of the world production [5].

Currently, tomato is very famous fruit and also used as a vegetable in most of the countries of the world. However, its production rate is low as comparison to demand of the peoples due to differences in variable environmental conditions, lack of high yielding varieties and poor cultural practices applied to fields of the crop. Furthermore, Lopes et al., [6] described that tomato plant is very sensitive to water stress. Therefore, proper and good productions of tomatoes require suitable watering throughout the life cycle. The commercial values of the table tomato is measured by the characteristics and quality of tomato fruit. Tomato fruit quality is determined mainly by his original color, good texture, and suitable flavor. Among those, color and flavor are probably two key characteristics for estimation of maturity of tomato fruit. High quality of tomato correlates with redness of color and prominence of flavor. The flavor of a tomato fruit becomes pronounced when sugar content in it observed maximum [7]. Tomatoes are planted by an estimated $85 \%$ of the gardens each year. Tomato is highly productive if it will be well managed [8]. Tomatoes during the wet and dry seasons contributed very high yield at national level but in southern states, bulk of production of the tomato fruit is observed in dry season [9]. Vegetable production are often adopted as a technique for improving bread, butter and better nutritional standing. It is a good solution to recover the issues of hunger within a country [10].

This crop makes people healthier and reduce the risk of different diseases that includes; cardiovascular disease, breast cancer, stomic cancer, esophageal cancer, pancreatic cancer and many other types. Some recent findings revealed that control of cancer activities by taken of tomatoes and garlic together [22]. Actually, few newly explored organic 
chemicals such as bioflavonoids from tomatoes are responsible for minimizing cancer fighting agents. Tomato fruit is also very effective for liver health. Detoxification effect was also noted in human body due to chlorine and sulfur content in tomato [23].

The objective of this preliminary study was to analyze the physio-chemical properties of soil of tomato growing areas in District Layyah, Pakistan. The growth parameters of commonly growing varieties of tomatoes were measured in this research project. Impacts of climatic conditions of the study area on fruit yields and nutritional values of selected tomato varieties were also under investigation. To recommend the best one variety for sowing in future in the study area.

\section{Materials and methods}

\section{Collection of soil samples}

Soil samples were taken from $10-16 \mathrm{~cm}$ depth. The samples were taken randomly from different locations of the selected experimental site. Then the collected samples were put in sun light for air-dried. After few days, samples were grinded by passing from $2 \mathrm{~mm}$ sieve tubes.

\section{Determination of physio-chemical properties of soil}

The collected soil samples were assessed for physio-chemical characteristics as following Bouyoucos and Walkley Black methods with some modifications. The size of soil particles were determined by applying Bouyoucos method [11]. Soil organic carbon was calculated by using Walkley black technique with few modifications [12]. Total nitrogen and phosphorus contents were determined separately which were present in the collected samples [13]. Similarly, other elements of soil collected samples were measured by use of atomic absorption spectrophotometer which includes exchangeable $\mathrm{K}, \mathrm{Ca}, \mathrm{Mg}$ and $\mathrm{Na}$ [14]. Soil samples $\mathrm{pH}$ in $\mathrm{H}_{2} \mathrm{O}$ (1:1) was also calculated by $\mathrm{pH}$ meter.

\section{Experimental design}

The experiment was conducted in a nursery. For the experimental work, two hybrid varieties of tomatoes and two indigenous tomato varieties were selected. The seeds were sowing in prepared plots in a row with specific distance. First, the prepared nursery plots were watered regularly with help of water cans. It was observed seedling emergence after each day. The seedling should start on the $5^{\text {th }}$ day after sowing. The nursery plots were mulched for good growth and germination of tomato plants. The plots prevented from excessive heat by a green sheet. The tomato nurseries were transplanted into their respective plots in the field after four weeks sowing periods [15]. Then, gradually measured the nutritional values and morphometric characteristics of the growing tomato varieties.

\section{Results and discussion}

The impact of climatic conditions and soils on growth and nutritional values of tomatoes were measured and documented in this current research work in the fields of District Layyah, Pakistan.

\section{Analysis of physio-chemical properties of soil}

The results of soil analysis viz., $\mathrm{pH}$, exchangeable cations, acidity and physical characteristics of soils were indicated in (Table 1). The pH 7.6 was measured. Available Phosphorus was calculated as $7.8 \mathrm{mg} / \mathrm{kg}$. Total Nitrogen appeared in collected samples was $0.6 \%$. $\mathrm{Ca}^{2+}$ showed maximum exchangeable cations $(2.9 \mathrm{mg} / \mathrm{g})$ as compared to other cations. In exchangeable acidity, Fe (ppm) indicated highest values (19.4 meg/100g). Physio-metric characteristics of soil were measured as sand $(76.5 \%)$, silt $(18.7 \%)$ and clay $(3.9 \%)$. The texture of soil appeared as sandy loam (Table 1). The nutritional values and soil characteristics of the investigated areas were also measured (Figure 1). 
Similar results were measured by many researchers in past who described the initial cropping soil analysis. The soil indicated sandy loam texture with rich organic matter and suitable moisture properties. It was observed that most of the chemical nutrient elements remained below the critical values. Similar findings were shown by Adeoye and Agboola [16]. On the other hand, suitable $\mathrm{pH}$ and inorganic fertilizer are necessary for better growth of vegetables. The soil changing particles like $\mathrm{pH}$ (7.0) and appropriate inorganic fertilizer were observed for tomato growth. So, tomato belongs to such a range were able to grow in these conditions $[17,18]$. The variation in nutritional values of tomato crop was incorporated due to presence of diversity of nutrients in soil $[24,26]$.

Analysis of nutritional values
Fruit analysis with special reference to cultivated tomato varieties were expressed in (Table 2). Statistically, the percentage of Magnesium, Protein contents, Calcium, Vitamin-C, Potassium and Phosphorus contents of tomato fruits were indicated significantly different values among the cultivated varieties. The statistical difference was also appeared in other nutritional contents. Highest (42.55\%) protein percentage produced by local variety $\mathrm{V}_{2}$ while lowest $(24.65 \%)$ percentage appeared in variety DT97/162A(R). On the other hand, highest $(41.50 \%)$ fat shown by variety DT97/162A(R). Fiber percentage appeared almost similar in all analyzed varieties. Vitamin C $(0.37 \mathrm{mg} / 100 \mathrm{~g})$ was measured highest in local variety $\mathrm{V}_{2}$ as compared to other varieties.

Table 1. Assessment of Physio-chemical properties of soil samples collected from the experimental sites (District Layyah, Pakistan)

\begin{tabular}{|c|c|c|}
\hline S. No. & Parameters & Analyzed Values \\
\hline 1 & $\mathrm{pH}$ in $\mathrm{H}_{2} \mathrm{O}$ & 7.6 \\
\hline 2 & $\mathrm{pH}$ in $\mathrm{Kcl}$ & 6.9 \\
\hline 3 & Total N (\%) & 0.6 \\
\hline \multirow[t]{2}{*}{4} & $\mathrm{P}(\mathrm{mg} / \mathrm{kg})$ & 7.8 \\
\hline & \multicolumn{2}{|c|}{ Cation exchangeable $(\mathrm{mg} / \mathrm{g})$} \\
\hline 1 & $\mathrm{Ca}^{2+}$ (Calcium ions) & 2.9 \\
\hline 2 & $\mathrm{Mg}^{2+}$ (Magnesium ions) & 2.6 \\
\hline 3 & $\mathrm{~K}^{+}$(Potassium ions) & 1.3 \\
\hline 4 & $\mathrm{Na}^{+}$(Sodium ions) & 1.0 \\
\hline \multirow[t]{2}{*}{5} & $\mathrm{Al}^{3+}$ (Aluminum ions) & 0.08 \\
\hline & \multicolumn{2}{|c|}{ Acidity (meq/100g) } \\
\hline 1 & C (Organic) & 2.8 \\
\hline 2 & $\mathrm{CEC}$ & 5.0 \\
\hline 3 & Nature of Acidity & 0.08 \\
\hline 4 & $\mathrm{Mn}$ & 5.4 \\
\hline 5 & $\mathrm{Fe}(\mathrm{ppm})$ & 19.4 \\
\hline 6 & $\mathrm{Cu}$ & 2.5 \\
\hline \multirow[t]{2}{*}{7} & $\mathrm{Zn}$ & 5.3 \\
\hline & \multicolumn{2}{|c|}{ Physical characteristics } \\
\hline 1 & Sand (\%) & 76.5 \\
\hline 2 & Silt (\%) & 18.7 \\
\hline 3 & Clay $(\%)$ & 3.9 \\
\hline 4 & Textural class & Sandy loam \\
\hline
\end{tabular}




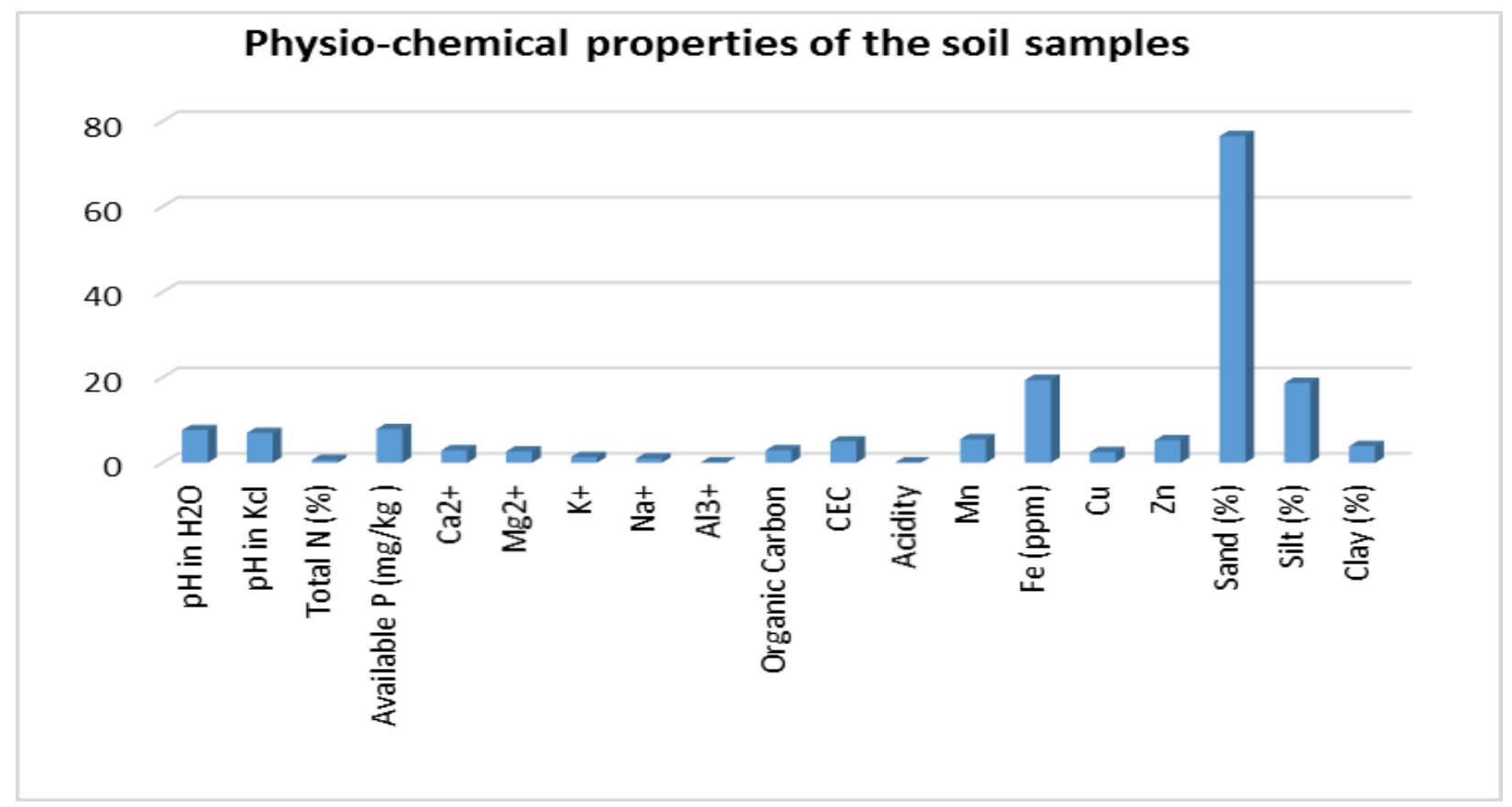

Figure 1. Assessment of Physio-chemical properties of soil samples

The highest values of $\mathrm{Ca}(0.395 \%), \mathrm{Mg}$ $(0.215 \%), \mathrm{K}(0.182 \%)$ and $\mathrm{P}(0.572 \%)$ were calculated from tomato local variety $\mathrm{V}_{2}$. These results were depicted that local variety $\mathrm{V}_{2}$ produced high nutritional contents. It may be adopted the environmental conditions easily and adjusted in the soil textures of District Layyah (Table 2). The nutritional contents of four analyzed varieties of tomato fruits were also compared in more distinct way (Figure 2).

Tomato is rich in nutritional values. It is a source nutrient in many countries. It was observed that all the four selected tomato varieties are good source of mineral elements and showed good quality. The observed variation in nutritive point of view against selected varieties of tomato might be due to environmental effects of the study area or soil textures in which they cultivated. The distribution of minerals is key factor which is needed for human health and required for human demand. Similar results were discussed previously by some authors in previous studies [19]. The proteins present in tomato fruit helpful in building up a new cells in the body and enhances growth of cells. Fats are also important part of balanced diet which is used as source of energy for man. Calcium supported the stiffness to body bones while Iron served as a source of blood production in human body $[10,18]$. Sometimes environmental stress or water stress was also influenced on nutritional variation of tomato fruit [25]. Therefore, in this study preferred the analysis of nutritional contents of tomato varieties in climatic conditions of the study area.

Table 2. Analysis of nutritional values of four selected tomato lines

\begin{tabular}{|c|c|c|c|c|c|c|c|c|}
\hline Tomato lines & $\begin{array}{c}\text { Protein } \\
(\boldsymbol{\%})\end{array}$ & $\begin{array}{c}\text { Fat } \\
\mathbf{( \% )}\end{array}$ & $\begin{array}{c}\text { Fiber } \\
(\boldsymbol{\%})\end{array}$ & $\begin{array}{c}\text { Vit. C } \\
(\mathbf{M g} / \mathbf{1 0 0 g})\end{array}$ & $\begin{array}{c}\mathbf{C a} \\
\mathbf{( \% )}\end{array}$ & $\begin{array}{c}\mathbf{M g} \\
(\boldsymbol{\%})\end{array}$ & $\mathbf{K}(\boldsymbol{\%})$ & $\mathbf{P}(\boldsymbol{\%})$ \\
\hline DT97/162A(R) & 24.87 & 41.50 & 5.9 & 0.32 & 0.243 & 0.108 & 0.084 & 0.429 \\
\hline DT97/215.A & 34.56 & 4.42 & 7.1 & 0.29 & 0.273 & 0.155 & 0.068 & 0.457 \\
\hline Local V1 & 29.34 & 3.72 & 6.7 & 0.19 & 0.302 & 0.185 & 0.137 & 0.455 \\
\hline Local V2 & 42.55 & 3.86 & 7.4 & 0.37 & 0.395 & 0.215 & 0.182 & 0.572 \\
\hline
\end{tabular}




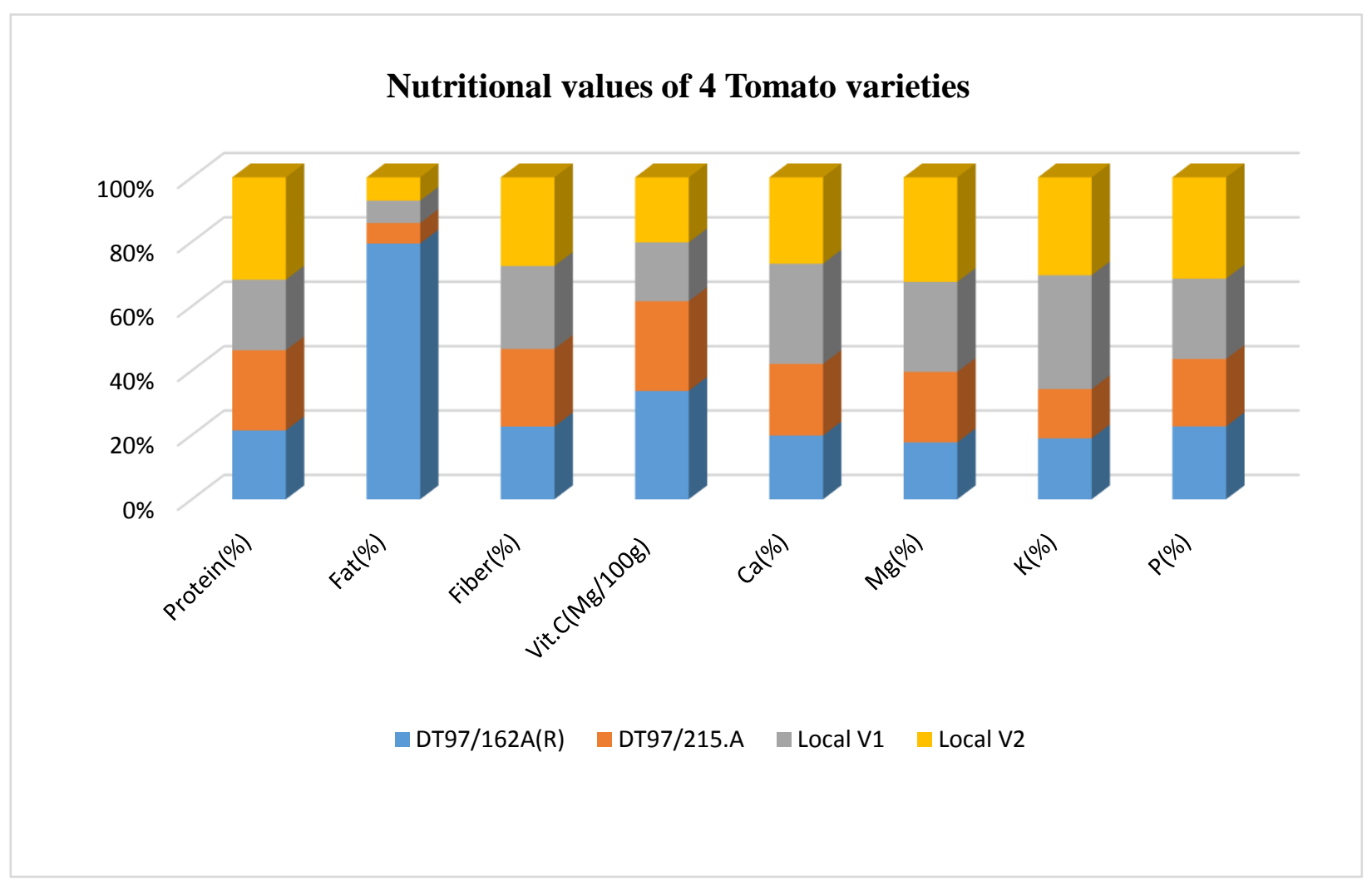

Figure 2. Analysis of nutritional values of four selected tomato varieties

\section{Measurement of morphometric characteristics}

The height of tomato plants, number of tomato leaves, number of flowers and fruits per plant of four tomato varieties were measured and it was observed that these characteristics were increased according to plant age as mentioned in (Table 3). These properties indicated significant differences between treatments against four varieties. However, variety $V_{2}$ had maximum plant height while DT97/215A variety indicated least height. The highest numbers of leaves were recorded from variety DT97/162A(R) while variety DT97/215A explored the less number of leaves. The number of leaves was increased as the tomato plants became mature. It was also observed that the statistical analysis showed significantly different readings among different treatments
(Table 3). Similarly, number of flowers and fruits were showed significantly similar distribution (Figure 3).

The growth patterns of tomato plants showed slow growth initially in the nursery plots and the growth accelerated more in the field after transplanting. These findings were strongly supported by many other scientist research papers $[18,20,21]$. All these findings revealed that environmental conditions distributes the better tomato production. Agro-diversity was also influenced on morphological characteristics of tomato fruit [27]. So, climatic conditions and soil contents were influenced on the growth and nutritional values of tomato varieties. Therefore, suitable environmental conditions should be provided for good production of tomato varieties in any country. 
Table 3. Measurement of characteristics of tomato plants after different treatments with regular time intervals

\begin{tabular}{|c|c|c|c|c|}
\hline Treatments & plant height & No. of leaves & No. of flower & Fruits per plant \\
\hline Local V1 & $1 \mathrm{~cm}$ & 3 & 4 & 3 \\
\hline Local V2 & $1.5 \mathrm{~cm}$ & 3 & 5 & 3 \\
\hline DT97162A® & $1 \mathrm{~cm}$ & 3 & 3 & 2 \\
\hline DT97/215A & $1 \mathrm{~cm}$ & 3 & 5 & 2 \\
\hline Local V1 & $3 \mathrm{~cm}$ & 5 & 5 & 3 \\
\hline Local V2 & $4.5 \mathrm{~cm}$ & 6 & 6 & 4 \\
\hline DT97162A® & $4 \mathrm{~cm}$ & 5 & 7 & 4 \\
\hline DT97/215A & $5 \mathrm{~cm}$ & 5 & 7 & 4 \\
\hline Local V1 & $5 \mathrm{~cm}$ & 7 & 6 & 4 \\
\hline Local V2 & $7 \mathrm{~cm}$ & 8 & 6 & 4 \\
\hline DT97162A® & $6 \mathrm{~cm}$ & 7 & 7 & 5 \\
\hline DT97/215A & $7 \mathrm{~cm}$ & 8 & 7 & 5 \\
\hline Local V1 & $6.8 \mathrm{~cm}$ & 10 & 6 & 4 \\
\hline Local V2 & $9 \mathrm{~cm}$ & 11 & 6 & 5 \\
\hline DT97162A® & $8 \mathrm{~cm}$ & 10 & 8 & 6 \\
\hline DT97/215A & $8.7 \mathrm{~cm}$ & 11 & 8 & 6 \\
\hline Local V1 & $7.4 \mathrm{~cm}$ & 11 & 7 & 6 \\
\hline Local V2 & $9.6 \mathrm{~cm}$ & 13 & 7 & 7 \\
\hline DT97162A® & $8.7 \mathrm{~cm}$ & 13 & 9 & 8 \\
\hline DT97/215A & $9 \mathrm{~cm}$ & 13 & 8 & 7 \\
\hline Local V1 & $8.8 \mathrm{~cm}$ & 12 & 8 & 8 \\
\hline Local V2 & $10 \mathrm{~cm}$ & 15 & 8 & 8 \\
\hline DT97162A® & $9.5 \mathrm{~cm}$ & 15 & 9 & 9 \\
\hline DT97/215A & $9.8 \mathrm{~cm}$ & 16 & 9 & 9 \\
\hline Local V1 & $9.3 \mathrm{~cm}$ & 15 & 8 & 9 \\
\hline Local V2 & $10.8 \mathrm{~cm}$ & 16 & 9 & 9 \\
\hline DT97162A® & $10.4 \mathrm{~cm}$ & 16 & 10 & 11 \\
\hline DT97/215A & $11 \mathrm{~cm}$ & 17 & 10 & 10 \\
\hline Local V1 & $9.9 \mathrm{~cm}$ & 17 & 9 & 10 \\
\hline Local V2 & $11.3 \mathrm{~cm}$ & 19 & 9 & 9 \\
\hline DT97162A® & $11 \mathrm{~cm}$ & 19 & 11 & 11 \\
\hline DT97/215A & $12.3 \mathrm{~cm}$ & 20 & 10 & 12 \\
\hline
\end{tabular}




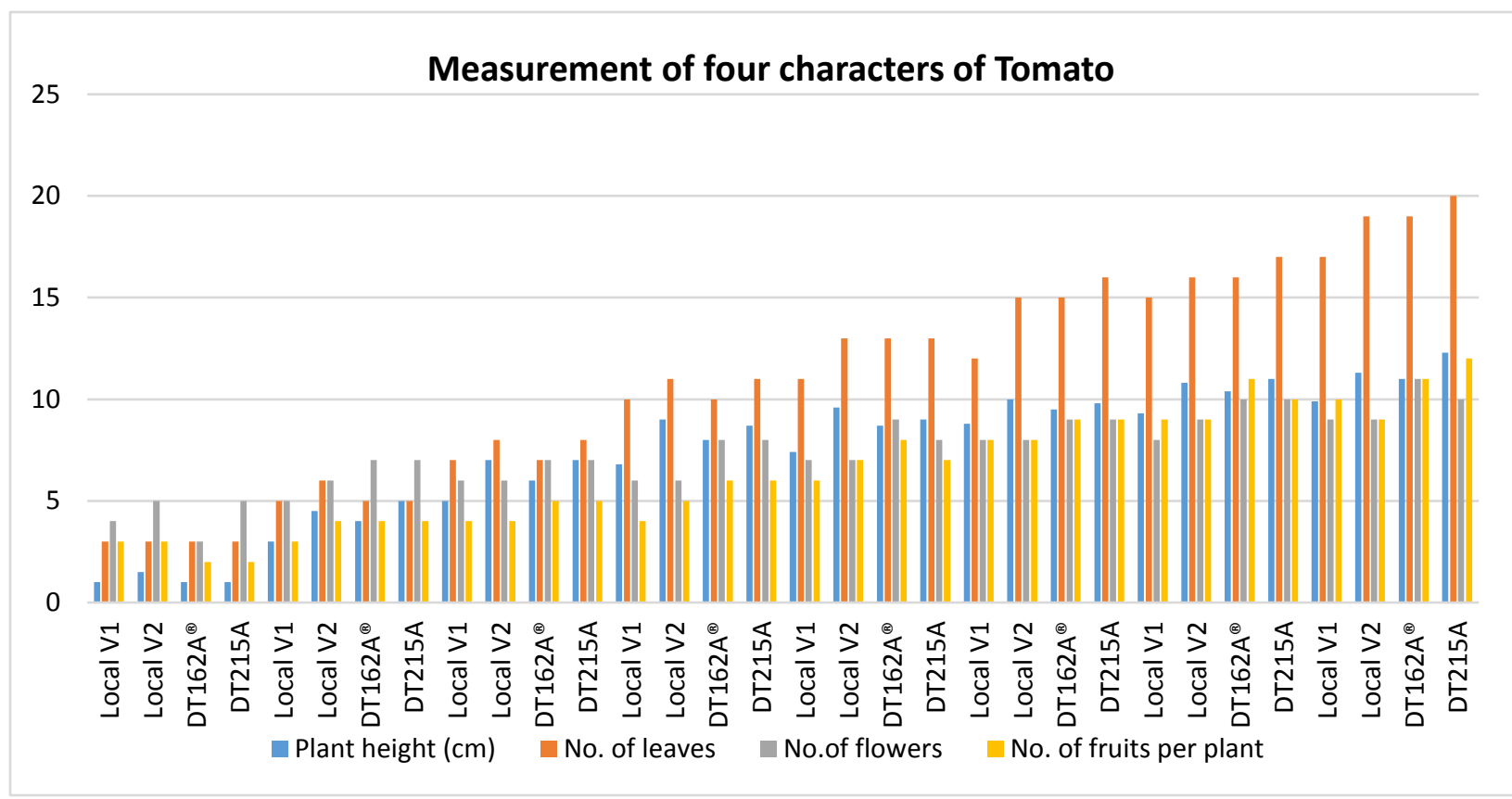

Figure 3. Measurement of morphological characteristics of tomato plants after different treatments with regular intervals

\section{Conclusion}

It was concluded that the fluctuated environmental diversity and other yield constraints prohibited by the selected tomato varieties during the period of growth and reproduction but still local variety $V_{2}$ produced highest yield, remarkable quality and better performance in the study area. This variety also indicated maximum nutritional contents. So, the variety $V_{2}$ tolerated the environmental conditions nicely in the study area and adjusted itself in the soil textures due to better genetic and resistant quality as comparison to remaining three investigated varieties. Therefore, local variety $\mathrm{V}_{2}$ recommended as the best tomato variety for future in District Layyah, Pakistan.

\section{Authors' contributions}

Conceived, designed and analyzed the experimental data: $\mathrm{T}$ Hussain, The experimental work was performed in nursery: S Thind, The paper was written: $S$ Thind \& $T$ Hussain, The other facilities like reagents, materials and analysis tools provided: I Hussain.

\section{References}

1. Chang KH, Wu RY, Chuang KC, Hsieh TC \& Chung RS (2010). Effects of chemical and organic fertilizers on the growth, flower quality and nutrient uptake of Anthurium andreanum, cuitivated for cut flower production. Scientia Horti 125: 434-441.

2. Shimbo S, Zhang ZW, Watanabe T, Nakatsuka H, Matsuda-Inoguch N, Higashikawa K \& Ikeda M (2001). Cadmium and lead contents in rice and other cereal products in Japan in 1998-2000. Sci of the Total Envin 281: 165-175.

3. Naika Van Lidt de Jeude SJ, De Goffau M, Hilmi M \& Van Dam B (2005). Cultivation of tomato production, processing and marketing. Agromisa Foundation and CTA, Wageningen pp 1-92.

4. Jensen CR, Battilani A, Plauborg Psarras FG, Chartzoulakis K, Janowiak F, Stikic R, Jovanovic Z, Li G, Qi X, Liu F, Jacobsen S \& Andersen MN (2010). Deficit irrigation based on drought tolerance and root signaling in potatoes and tomatoes. Agri Water Manag 98: 403-413.

5. Matos ES, Shirahige FH \& Melo PCT (2012). Desempenho de híbridos de tomate de crescimento indeterminado em funcao de 
sistemas de condução de plantas. Horti Brasi 30: 240-245.

6. Lopes CA, Ávila AC, Reis A, Inouenagata A, Quezado Duval AM, Henz GP, Charchar JM, Boiteux LS, Giordano LB \& Melo PCT (2005). Doenças do tomateiro. 2 ed, Brasilia: Embrapa Hortaliças pp 151.

7. Ferreira SMR, Freitas RJS \& Lazzari EN (2004). Identity and quality standards of tomatoes (Lycopersicon esculentum Mill.) for fresh consumption. Ciencia Rural 34:329-335.

8. Denton L \& Swarup V (1989). Tomato cultivation and its potential in Nigeria. Acta Horticulturae. Sixth African symposium on Horticultural crops. Ibadan 123: 257-265.

9. Anon (1989). A guide to production of some vegetables (NIHORT's extension guide No. 8.

10. South Pacific Foods (1995). Green leaves. In: South pacific foods leaflets. South pacific commission, community Health Services 6 leaflet.

11. Bouyoucos GJ (1962). Hydrometer method improved for making particle size analysis of soil, Agronomy J 53: 464-465.

12. Black CA (1965) .Methods of soil Analysis. Agronomy No. 9 Part 2, Am Soc Agron 2: 510.

13. Technician Instrument Corporation (1975). Industrial method No. 155-71 W.

14. Tel A \& Hargerty M (1984). Soil and plant analyses study guide for agricultural Laboratory directors and technologies working in tropical regions IITA and University of Gueloh. pp 227.

15. Adelana BO (1975). Effect of staking on growth and yield of tomatoes, E Afr $J$ 41: 243-249.

16. Adeoye OA \& Agboola AA (1985). Critical level of soil plant available $\mathrm{PK}, \mathrm{Zn}, \mathrm{Mg}, \mathrm{Cu}$ and $\mathrm{Mn}$ on Maize leaf content in sedimentary soils of southwestern Nigeria. Fert Research 6: 60-71.

17. Tindal HD (1983). Vegetable crops of the lowland tropics. Oxford University Press, Oxford pp. 101-125.
18. Olaniyi JO, Akanbi WB, Adejumo TA \& Akande OG (2010), Growth, fruit yield and nutritional quality of tomato varieties. Afri $J$ of Food Sci 4(6): 398-402.

19. Russo VM (1996). Cultural methods and mineral content of Eggplant (Solanum melongena) fruits. J Sci Food Agric 71: 119123.

20. Olaniyi JO \& Fagbayide JA (1999). Performance of eight Fl Hybrid Cabbage (Brassica oleracea L.) varieties in the southern Guinea Savanna zone of Nigeria. $J$ Agric Biotechnol Environ 1: 4-10.

21. Fogg GE (1969). The growth of plants. Penquin Books. IITA (1989) pp. 14-15.

22. Bhowmik D, Kumar KP, Paswan S \& Srivastava S (2012). Tomato-a natural medicine and its health benefits. $J$ of Pharmac and Phytoch 1(1): 33-43.

23. Polivkovaa Z, Smerak P, Demova H \& Houska M (2010) Antimutagenic Effects of Lycopene and Tomato puree. $J$ of Medic Food 13(6):1443- 1450.

24. Vinha AF, Alves RC, Barreira SVP, Castro A, Costa ASG \& Oliveira MBPP (2014). Effect of peel and seed removal on the nutritional value and antioxidant activity of tomato (Lycopersicon esculentum L.) fruits. LWT-Food Sci Technol 55, 197-202.

25. Lahoz I, Perez-de-Castro A, Valcarcel M, Macua JI, Beltrand J, Roselloc S \& CebollaCornejo J (2016). Effect of water deficit on the agronomical performance and quality of processing tomato. Sci Hortic 200: 55-65.

26. Borgognone D, Colla G, Rouphael Y, Cardarelli, M, Rea E \& Schwarz D (2013). Effect of nitrogen form and nutrient solution $\mathrm{pH}$ on growth and mineral composition of self-grafted and grafted tomatoes. Sci Hortic 149: 61-69.

27. Rocchi L, Paolotti L, Cortina C \& Boggia A (2016). Conservation of landrace: The key role of the value for agrobiodiversity conservation. An application on ancient tomatoes varieties. Agric Sci Procedia 8: 307-316. 